\title{
Language as Symbolic Action
}

A Burkean Analysis of Césaire's Cahier d'un retour au pays natal

\section{Chelsea R. Binnie}

Journal of French and Francophone Philosophy - Revue de la philosophie française et de langue française, Vol XXIII, No 1 (2015) pp 59-78.

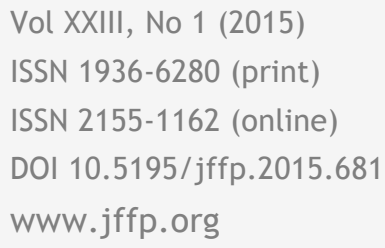

\section{(c) EY-NC-ND}

This work is licensed under a Creative Commons Attribution-Noncommercial-No Derivative Works 3.0 United States License.

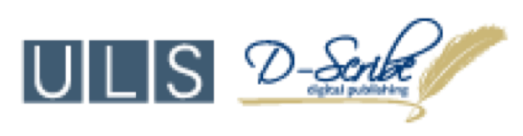

This journal is operated by the University Library System of the University of Pittsburgh as part of its D-Scribe Digital Publishing Program, and is co-sponsored by the University of Pittsburgh Press 


\title{
Language as Symbolic Action A Burkean Analysis of Césaire's Cahier d'un retour au pays natal
}

\author{
Chelsea R. Binnie
}

Duquesne University

Aimé Césaire, the Martiniquan-born black French intellectual whose work, in conjunction with that of Léopold Sedar Sénghor and Léon-Gontran Damas, birthed the idea of Négritude, or black consciousness, formulated a critical rejection of the colonial order during the French surrealist movement. Césaire's epic poem Cahier d'un retour au pays natal details Négritude's rejection of colonial values and glorifies those of African origin. Cahier rejects traditional Western philosophical values grounded in logic and reason and pleads for a return to wholeness through communion with Mother Earth. This paper works to analyze Césaire's Cahier through the lens of Kenneth Burke's Language as Symbolic Action: Essays on Life, Literature, and Method. The paper will look particularly to Burke's definition of man, thought on symbolic action, and understanding of poetry and poetics when analyzing Césaire's Cahier. The essay seeks to examine Césaire's plea for wholeness and unity through Burke's understanding of language as representative of symbolic action.

This paper sets out to put Kenneth Burke's thought on language as representative of symbolic action into conversation with Aimé Césaire's epic poem, Cahier d'un retour au pays natal. The paper is divided into three main sections that set the stage for Burke and Césaire's work to converse. The first section lays out an overview of Kenneth Burke's thought on language paying particular attention to his definition of man, understanding of symbolism and symbolic action, and thoughts on poetry and poetics. The second section provides a working history of African philosophy, the Négritude movement, Césaire as a philosopher, politician, and poet, and provides an overview of main themes and intentions present in Cahier. The third section works to put Burke and Césaire into conversation by using Burke's understanding of symbolic action and his notion of order and identification to examine key passages from Césaire's Cahier. The paper

Journal of French and Francophone Philosophy | Revue de la philosophie française et de langue française Vol XV, No 1 (2011) | www.jffp.org | DOI 10.5195/jffp.2015.681 
works to present an informative and textured engagement between the work of Kenneth Burke and Aimé Césaire.

Putting Burke's thought on language as representative of symbolic action into conversation with Césaire's Cahier demonstrates how a critical textual analysis can work to elucidate new meaning and understanding. Césaire's Cahier is an incredibly powerful poem that is packed full of a complex multiplicity of meaning and being. In the lines of Cahier Césaire simultaneously speaks to his own experience of being black in the world, of his return to Martinique, of his formal break and rejection of the Western philosophical tradition, and of his fellow black man's being in the life world. Applying Burke's thoughts on symbolic action to Césaire's meaning-laden Cahier provides the reader with tools to begin unpacking both the literal and the symbolic as well as the biological and the mechanical meanings and representations present within the poem. Burke's work on symbolic action provides the reader with a point of departure for engaging the full complexity and multiplicity of textual references, meaning, and being portrayed in the lines of Césaire's epic poem.

\section{Burkean Perspectives on Language as Symbolic Action}

Kenneth Burke's definition of man sets out to examine the totality of the condition of being human. Burke spells out his definition of man in the 1968 book, Language as Symbolic Action: Essays on Life, Literature, and Method. According to Burke:
Man is
the symbol-using (symbol-making, symbol-misusing) animal
inventor of the negative (or moralized by the negative)
separated from his natural condition by instruments of his own
making
goaded by the spirit of hierarchy (or moved by the sense of order)
and rotten with perfection. ${ }^{2}$

In his definition of man Burke examines man as "the symbol-using animal" who is also the "inventor of the negative." These descriptors highlight man's capacity to both create and use language-a capacity that sets man apart from every other living creature. Burke views man as "separate" from his "natural condition" and cites "instruments of his own making" as the cause for the separation between man and his "natural condition." ${ }_{2}$ This recognition of man being in his natural condition but at the same time being separated from his natural condition by his own hand is significant because it point's to man's ability to engage the world through a multiplicity of states

Journal of French and Francophone Philosophy | Revue de la philosophie française et de langue française

Vol XV, No 1 (2011) | http://www.jffp.org | DOI 10.5195/jffp.2015.681 
of being - in this case, natural being — as man was made, or separate beingbeing separated from his natural state of being by conditions of man's own making.

Further examination of Burke's definition of man reveals that man is "goaded" by the "spirit of hierarchy," or put another way, is "moved" to action by a "sense of order." ${ }^{3}$ This clause in the definition of man points to the social nature of man's being. In order for a "spirit of hierarchy" or a "sense of order" to exist, man must be in the world in conjunction and participation with other beings. Man's recognition of other beings in the world forces him to recognize the other's existence and he does so through comparison with his own being. Both a "spirit of hierarchy" and "a sense of order" require man to examine his being in light of his fellow man's being so he can see how he measures up. When this act of measuring is applied on a social scale, groups of like-minded beings separate themselves from groups of other-minded beings. The introduction of social comparison allows a "spirit of hierarchy" and a "sense of order" to be born as groups of likeminded beings separate themselves from other-minded beings resulting in classifications based on difference. The final clause of Burke's definition of man indicates that man is "rotten with perfection"." In discussion of "perfection" Burke points to the Aristotelian principle of entelechy, or "the notion that each being aims at the perfection natural to its kind" and later confines "use of the principle to the realm of symbolic action." ${ }^{\text {s }}$ This understanding of perfection as entelechy is significant because it indicates that the possession of an internal will is intrinsic in the nature of being human. The notion of perfection as entelechy drives man to action in the natural world and symbolic action in the linguistic realm.

Burke explores the notion of symbolic action heavily throughout his works, particularly in his work regarding dramatism. In dramatism, the nature of a symbolic action may or may not be "readily apparent" ${ }^{\circ}$. In discussion of Burke's thought on dramatism and symbolic action, Robert Garlitz indicates that Burke's understanding of human action as symbolic can manifest in one of two ways. First, symbolic action can manifest through the forms of "language," "styles of music," "painting," "sculpture," or "dance," in addition to other forms. Second, Garlitz is careful to point out that human action can also become symbolic because of "motives which are not readily apparent." " This dual understanding of symbolism and symbolic action points to the "empirical distinction" Burke claims that "all men make between their approach to 'people' and their approach to 'things'.". Burke indicates that dramatism marks a careful difference "between mental action and mechanical motion" which science does not make. According to Burke, "'scientific' language is the very opposite of rhetoric." "This distinction is significant because it underscores the capacity of symbolism, or symbolic action, to move or inspire man to action while at the same time drawing a careful distinction between the rhetorical capacities inherent within 
symbolic action and those of science-rhetorical capacities that Burke finds science to lack.

In his 1984 book Attitudes Toward History Burke discusses the notion of symbolism as a complex form of "spiritual currency." "According to Burke, this "spiritual currency" can be manipulated to meet a certain group's "special benefit" even if the group's efforts are not "consciously directed to this end." ${ }_{12}$ The results of this "special benefit" tend to include "dispossession and alienation" largely occurring as unintentional "byproducts." ${ }_{13}$ Burke turns his attention to the use of motivation to move man from symbolism to action. In A Rhetoric of Motives Burke focuses his attention on "public and private orders of motivation." ${ }_{14}$ Burke indicates that the public order of motivation "praises the just and the beautiful," while the private order of motivation "prefers the test of expediency." ${ }_{15}$ The task of the orator, in Burke's view, is to "use whichever of these orders better suits his purposes" when working to move man to a desired end, in this case, that of action. Burke's rhetorician therefore finds himself "shuffling" between idealistic and materialistic motives that are situated in both public and private spaces when working to inspire man to action. ${ }^{16}$

Burke further examines the notion of language as representative of symbolic action in chapter four of Language as Symbolic Action. Burke points to his definition of man as "the symbol-using animal" and states that motives can be derived from his "animality," "symbolicity," or "from mixtures of the two." ${ }_{17}$ Burke draws a distinction between the way man treats other beings and the way he treats objects or things. In consideration of symbolic action, or action that is embodied by language, Burke calls for a distinction between the symbolic action of a "person" and that of "a mere thing." "Burke's distinction between the action of a person and that of a thing highlight man's innate capacity to engage in thinking, willing, and acting. Human beings can will themselves into action and will other beings or objects (things) into action as well. Things, on the other hand, can be moved to action, but cannot do so at their own hand, as the nature of being an object in the world leaves objects (or things) devoid of the capacity to engage independent thought. This distinction between human symbolic action and the symbolic action of a thing reinforces the significance of man's capacity to think, will, and act on both a biologic and symbolic level in the life world.

Burke continues his discussion of symbolic action in his 1989 text On Symbols and Society by turning his attention toward the language of poetry. For Burke, "poetry, or any verbal act, is to be considered as 'symbolic action'." ${ }_{19}$ Burke states that poetry should be used for "the adopting of various strategies for the encompassing of situations." ${ }_{20}$ Burke finds "strategies" to be useful because they can examine "situations" and determine their "structure and outstanding ingredients." ${ }_{21}$ This information, in turn, assists man in naming "situations" in a manner that demonstrates "an attitude toward them." 22 Burke indicates that the "situations" are

Journal of French and Francophone Philosophy | Revue de la philosophie française et de langue française Vol XV, No 1 (2011) | http://www.jffp.org | DOI 10.5195/jffp.2015.681 
universal because they are real-they contain "public content" and "overlap from individual to individual" and "from one historical period to another." When an attitude toward a particular situation meets symbolic action, the poem serves as a forum through which the "whole body may finally become involved." ${ }^{24}$ In Permanence and Change Burke discusses a close link between "the devices of poetry" and "the spontaneous genius of man." ${ }_{25}$ This linkage between poetry and man points to the notion of "poetic standards" that are "'biologically' grounded." ${ }^{26}$ The link between poetry and man gives poetry a certain "authority" that is not offered "as revelation" but is instead "based upon pragmatic demands." ${ }^{2}$ Burke indicates that this is an important fact because poetry must lay claim to symbolic authority in the very authority or authoritative structure it seeks to displace.

Burke's discussion of attitude as a device of poetry is also present in his 1973 text, The Philosophy of Literary Form: Studies in Symbolic Action. Burke enters into discussion of the semantic ideal, or that of language, and the poetic ideal, or that of attitude or emotion. Burke indicates that the semantic ideal attempts "to get a description by the elimination of attitude" whereas the poetic ideal attempts "to attain a full moral act by attaining a perspective atop all the conflicts of attitude." ${ }_{28}$ Burke finds the semantic ideal working to "cut away" or "abstract" any and all "emotional factors" that might obscure the "clarity of meaning." ${ }_{20}$ The poetic ideal works to derive meaning from the "heaping up" of "all these emotional factors." "s Burke indicates that the poetic ideal looks to "emotional factors" to provide a certain texturing and clarity to meaning. In other words, the poetic ideal examines "emotional factors" from many angles-going so far as to play them off one another, "invit[e] them to reinforce and contradict one another," and "seek[s] to make this active participation itself a major ingredient of the vision"-in order to attain a "clarity of meaning." " approach to generate clarity of meaning through its embodiment of attitude and emotion that is tied to (not separated from as in the case of the semantic ideal) man's capacity to both symbolically and biologically inspire and create meaning in the life world.

\section{African Philosophy, Négritude, Césaire and Cahier}

The work of Placide Tempels helps to lay a foundation for understanding the project of African Philosophy. Tempels' work is grounded in the desire to make a statement that is both deeply connected to and pushes against the colonial project. Tempels' work sets out to preserve "the humanity of the African" and the "honors" with which "philosophy has been associated from antiquity." ${ }_{32}$ According to J. Obi Oguejiofor, "being black or African did not have any negative connotation among the ancients." ${ }^{33}$ In antiquity, black beings were "taken as artistic models" and were able to "mount and descend the social ladders in the Greco-Roman world." ${ }^{34}$ This information is 
important because it points to a model of communicative and ontological inclusion that is not present today. The experience of slavery, largely a byproduct of "the thinkers of the Enlightenment," permitted "race prejudice against Africans" to emerge. According to Oguejiofor the notions of prejudice and racism were not prominent until the Enlightenment and manifested in the inhumane forms of "transatlantic slavery, colonialism, and imperialism." ${ }^{35}$ Oguejiofor's work indicates that the African man's capacity to be in the world was stripped from him-if not outright ignored-during the largely European scramble to claim pieces of Africa by any means necessary.

In his 1993 article, "Issues in African Philosophy Re-Examined," Fidelis U. Okafur looks to the work of Kwame Nkruman, Julius Nyerere, Léopold Sédar Senghor, Sékou Touré, Frantz Fanon, and Aimé Césaire as a set of African (and Afro-Caribbean) nationalists and philosophers deeply concerned and driven by the fate of Africa and its people. Okafur indicates that the philosophy that emerged from these individuals was either concerned with "the struggle for emancipation of the African continent from the clutches of colonialism" or desired to construct a "characteristically African social and political philosophy" so as to establish and preserve an "authentic African social and political order." ${ }_{36}$ Césaire and the Négritude project fall under the veil of African philosophy by Caribbean extension and came into being out of a desire "to obliterate the cultural heritage of the new French people." ${ }_{37}$ The movement sought to "assert" the "existence" of Africans and to project a "sense of value" onto their cultural heritage in a way that contributed to humanity. ${ }^{38}$ Négritude, as an offshoot of African philosophy found roots in the confluence of philosophical, social, and political tensions present in and between the Caribbean, France, and Africa.

The word, "Négritude" is French in origin and can be translated into English to signify "blackness" or "black consciousness." Aimé Césaire, from the Windward, Lesser Antillean island of Martinique, is first credited with using the term in 1935 in the journal L'Etudiant Noir. ${ }^{3{ }^{9}}$ Césaire, in conjunction with Léon-Gontran Damas of French Guyana, and Léopold Sédar Senghor of Senegal, West Africa, came together in Paris in "the mid to late thirties in response to a situation that alienated them and their cultural values." result of their collaboration led to the birth of the Négritude project as a social, political, literary, and cultural movement intended to reclaim wholeness in the condition of black being in the world. Chukwudum B. Okolo indicates that Négritude "was by no means a mere intellectual reaction to alienated consciousness" rather, it was "above all an affirmation of being" or, an affirmation of the wholeness of black consciousness or black being. ${ }^{41}$ Négritude called for a unity of the black man in his natural state rather than a separation from his natural state driven by social and political standards-in this sense, Négritude calls for a reclamation of being rather than a separation of man from his natural state by devices of his own making. ${ }^{2}$

Journal of French and Francophone Philosophy | Revue de la philosophie française et de langue française Vol XV, No 1 (2011) | http://www.jffp.org | DOI 10.5195/jffp.2015.681 
Chike Onwachi discusses the ideological implications of Négritude in his 1972 text, African Identity and Black Liberation. For Onwachi, the ideology of Négritude indicates that "Africa, like all other human worlds, must be viewed and understood in terms of the African people's collective experience and effectiveness." ${ }_{33}$ According to Onwachi, "Africa must be appreciated for what she is, and not for what the European world wants Africa to be or wants to make out of Africa." ${ }^{4}$ Aimé Césaire echoes this call for the appreciation of Africa and the African in light of their natural state of being in the world in his text Discourse on Colonialism. Césaire states that "[w]e were Negroes" and "we were proud of it." ${ }_{45}$ Césaire continues by indicating that Négritude did not view Africa as "some sort of blank page in the history of humanity" but rather it "asserted that our negro heritage was worthy of respect." " ${ }^{46}$ For Césaire, this history "was not relegated to the past" and "its values were values that could still make an important contribution to the world." "Césaire's conception of Négritude cries for a unity of Africa and the African regardless of his worldly location-which oftentimes was changed against his will as a result of Enlightenment thinking that brought notions of prejudice and race to the forefront of social thought and conversation in the Western world.

Aimé Césaire's Cahier d'un retour au pays natal was first published in Volontés in 1939. Césaire published Cahier in Paris, France, just prior to returning to his native Martinique. Césaire left formal schooling in Paris and returned to his native land via ship "three days after the beginning of World War II." ${ }_{48}$ The ship that carried Césaire back "to Martinique was sunk on its way back to Europe by the Nazis." ${ }^{4}$ Shortly following his return, the Nazis sent "the Vichy rule of the notorious Admiral Robert" to the island accompanied by "thousands of racist French sailors." ${ }_{s 0}$ As one might imagine, this was a less than ideal homecoming. Césaire returned to Martinique in 1939 with his family and underwent an identity crisis that resulted in his "conversion from model student to poet." ${ }_{51}$ Gregson Davis indicates that Césaire's Cahier emerged as Césaire forged his "poetic voice"-put another way, Cahier came to be as a result of Césaire's "emergent obsession" to "re-channel his mental energies." ${ }_{52}$ Cahier came into being as a result of a very turbulent time in the life of Césaire-according to Davis, the "birth of négritude was by no means painless." "ss The result of Césaire's refocused attention and response to these less than desirable living conditions can be seen throughout the pages of his Cahier.

In Cahier, Césaire pushes against the colonial project on both a deeply personal and societal level. Césaire intends to call "into question our present understanding of man's humanity" through the "exorcism of the depths of alienation of his own socialized consciousness." ${ }_{54}$ Sylvia Wynter indicates that Césaire's Cahier can be read as "a great cadenced outburst" that pushed Césaire to demonstrate "a radical discontinuity with contemporary Western thought." ${ }_{s 5}$ Césaire's reason for breaking with Western philosophy came to

Journal of French and Francophone Philosophy | Revue de la philosophie française et de langue française Vol XV, No 1 (2010) | http://www.jffp.org | DOI 10.5195/jffp.2015.681 
be as a result of Western philosophy's adoption of "the one-sided technoindustrial goal" which gave primacy to the "mastery of nature/mastery of Natural Scarcity" that was understood to be "the Absolute criterion of being human." ${ }^{56}$ In other words, Césaire broke with the Western philosophical tradition because it lost its connection to man in his natural state when it adopted the "one-sided technological goal" and gave primacy to the "mastery of nature" as "the Absolute criterion" for being human. Césaire pushed against Western philosophy in his writing by taking to the poetic form. Cahier serves as a prime example of "his poetic ideal of a strong black identity" that he put into practice by poetically "promoting the sociopolitical concerns" of the Martiniquais. ${ }^{57}$ Césaire's Cahier serves as a literary representation of his rejection of the Western philosophical tradition, which he demonstrates poetically by using colonial language to push against the very system that oppressed both he and his fellow Martiniquais.

\section{Kenneth Burke and Aimé Césaire in Conversation}

Bernard L. Brock, Kenneth Burke, Parke G. Sturgess, and Herbert W. Simons highlight two dominating worldviews - the personalistic and the technological. For Brock et al., the personalistic worldview reflects "a religious view" which leads to "conceptions of the self, the family, the tribe, and the entire social structure." "The technological worldview is characterized by "machinery" that "accounts for the human condition." Césaire rejects the technological worldview which he finds to be representative of the Western philosophical tradition. From a Burkean perspective, the technological worldview highlights the third clause in his definition of man wherein man is "separated from his natural state by conditions of his own making." ${ }_{60}$ Burke's understanding of the technological worldview points to man's being in his natural state as well as to his being separated from his natural state by his own devices. Césaire's philosophical orientation would be more akin to the personalistic worldview wherein man being in his natural state is afforded primacy over a desire to impose man's will over nature. Burke's worldview embodies exactly what Césaire sets out to explode, which is the orientation that man can afford himself the capacity to exact his will over nature, or over any living being in the life world. Burke's technological worldview signifies both a unity with and a separation from man in his natural condition. Such an orientation would prove damaging to Césaire's personalistic worldview wherein he champions man's capability to exist in his natural state absent the desire to engage in acts of domination directed at nature, more broadly, or other beings, more specifically.

Though Burke works from the Western philosophical tradition some parallels can be seen between his work and that of Césaire's when the work of each is examined in terms of its linguistic capacities. For Burke, man is a

Journal of French and Francophone Philosophy | Revue de la philosophie française et de langue française

Vol XV, No 1 (2011) | http://www.jffp.org | DOI 10.5195/jffp.2015.681 
"specifically symbol-using animal" that "introduce[s] a symbolic ingredient into every experience." "61 According to Burke, "sheer 'animality' is not possible to the sensory experiences of a symbol-using animal" because "every experience will be imbued with negativity." ${ }_{22}$ In other words, man can never experience true "animality" because his symbol-using nature does not allow him to engage sensation on its own terms-the symbol-using animal "introduce[s] a symbolic ingredient into every experience." " ${ }^{\star 3}$ In a 1985 article titled "Dramatism and Logology" Burke indicates that "[s]ymbolic action in general involves its use for persuasion." ${ }^{\circ}$ Burke continues stating that "symbolic action" can also be used for "first principles," "the spread of information," "love of art," or, as "the exercise of symbolic action for its own sake (poetics)." ${ }_{65}$ According to Burke, the use of "symbolic action" for persuasion, or the "practice of rhetoric can lead to new knowledge because the doing or experiencing of anything can lead to new knowledge." ${ }_{6 r}$ Burke's understanding of man as the symbol-using animal and symbolic action provides one with a critical tool set from which to begin interpreting Césaire's Cahier. If man as the "symbol-using" animal introduces a "new symbolic ingredient" into every experience a being has, and if "symbolic action" generally is "use[d] for persuasion," then man as the "symbol-using" animal introduces a new persuasive ingredient into every experience he has. ${ }^{67}$ When Burke's understanding of man and symbolic action are examined in this light, the reader is provided with linguistic tools to open Césaire's Cahier in a way that allows one to grasp the full complexity of the being(s) depicted within Césaire's prose.

One can begin this Burkean examination of Césaire and Cahier by looking to the events from which the text emerged. Césaire published Cahier in 1939 and formally left the European continent to return to his native Martinique on September 1 of that same year-just three days after the formal beginning of World War II. ${ }^{\star}$ Frantz Fanon considered Césaire's return to Martinique "to be of crucial symbolic importance for ideas of Martiniquan identity." ${ }^{\prime}$ Michael Richardson and Krzysztof Fijalkowski find it "symbolic that the ship that carried him [Césaire] home would be sunk by the Nazis on its return journey." " According to Richardson and Fijalkowski, Césaire's return to Martinique "announced a definitive break with the values of Europe." "When Césaire's act of returning to Martinique is examined in light of Burke's understanding of symbolic action it becomes clear that Césaire is not simply acting on a literal level-his actions are imbued with a multiplicity of meanings and significance that are also prominent in his prose. C.L.R. James understood Césaire's Cahier to be significant in three ways. First, Césaire united "the African sphere of existence" with "existence in the Western world." Second, Césaire demonstrated an historical and a logical link between the "past of mankind and the future of mankind." Finally, Césaire inspired a "self-generated" and "independent being" to help move "Africa and Africans" toward "an integrated humanity." ${ }^{\prime}$ C.L.R. James' understanding of the significance and

Journal of French and Francophone Philosophy | Revue de la philosophie française et de langue française Vol XV, No 1 (2010) | http://www.jffp.org | DOI 10.5195/jffp.2015.681 
complexity of Césaire's Cahier further reinforces the necessity and utility of Burke's thought on symbolic action as a persuasive expression of the experience of human being in the life world that leads to the creation of new knowledge. In other words, using Burke's thought on symbolic action as a lens through which to examine Césaire's Cahier permits the reader to transcend the varying layers of complexity that are representative of Césaire's experiences in the life world, the experiences of blacks in the life world, and of a formal break with the philosophical tradition that imposed Enlightenment notions of race and prejudice upon black being in the life world.

Césaire's Cahier is first and foremost an epic poem that details his return to Martinique, his and the experience of being black in the world, and of his break with the Western philosophical tradition that subjugated he and other blacks, in addition to other themes. Césaire was heavily influenced by the surrealism movement when writing Cahier and saw it as "a poetic tool, a means to use language, and a moral sensibility." Césaire was able to attain "confirmation" of what he had uncovered in his "own reflections." ${ }_{74}$ According to Césaire, "all great poetry, without ever renouncing its humanity, ceases to be strictly human and starts to become truly cosmic." "Césaire continues that "through the poetic state" two of "the most agonizing antinomies possible are resolved: the antinomy of self and other and that of the Ego and the World." ${ }_{76}$ Césaire viewed the "surrealist approach" as a way to summon "unconscious forces" in his writing." For Césaire the "surrealist approach" offered him a literary tool with which he could dig past his superficial French appearance-traceable through the presence of French customs, familiarity with Cartesian philosophy, and the presence of French rhetoric-masking the depths of his being which, in his own words, "is fundamentally black." ${ }^{78}$ When putting Césaire's preference for surrealism in conversation with Burke's thought on symbolic action one is able to notice a bit of an overlap in terms of literary intent. Césaire's Cahier works to depict first and foremost the experience of being black in the life world. When this depiction is understood in terms of Burke's symbolic action, or action that is (poetically) representative of lived experience, the reader is able to begin to digest the complexity and multiplicity of being and meaning present in Césaire's epic poem.

The notion of order is also important to understand when examining Burke's thought on language as representative of symbolic action in light of Césaire's Cahier. According to Burke, language assists in clarifying meaning in three major ways. First, through "order." Burke states that "once a sentence is formed, it is necessarily a series of words released in a certain order." ${ }^{\prime \prime}$ Second, language assists in clarifying meaning through "differentiation of grammatical function." "Finally, language clarifies meaning through "growth of vocabulary" which can take place through "new words" or through the "metaphorical extension of old words."

Journal of French and Francophone Philosophy | Revue de la philosophie française et de langue française

Vol XV, No 1 (2011) | http://www.jffp.org | DOI 10.5195/jffp.2015.681 
of these three ways, for Burke, moves in "the direction of definiteness" or toward clarity of meaning. ${ }^{.2}$ For Burke, the notion of order is of particular importance which he discusses at length in The Rhetoric of Religion. Here, he presents his concept of order in the form of a poem:

Here are the steps

In the Iron Law of History

That welds Order and Sacrifice:

Order leads to Guilt

(for who can keep commandments!)

Guilt needs Redemption

(for who would not be cleansed!)

Redemption needs Redeemer

(which is to say, a Victim!).

Order

Through Guilt

To Victimage

(hence: Cult of the Kill). . . .83

Burke discusses the notion of order in The Rhetoric of Religion to "study the point at which narrative forms and logical forms merge (or begin to diverge!)," or, put another way, to study the "exquisite point" of differentiation between "purely temporal and purely logical principles of 'priority'." " For Burke, the notion of a "sacrificial principle" is "intrinsic to the idea of order" - in other words, order provides a "logological' reaffirmation of the foibles and quandaries that all men (in their role as 'symbol-using animals') have in common." "In a 1942 article titled "War and Cultural Life," Burke discusses the notion of order in light of identification. According to Burke, "identification between the leaders and the led" as a result of "hortatory or admonitory rhetoric" presents information in ways that "cushion the discouragement of defeats" and "intensify the encouragement of victories." ${ }^{\text {ss }}$ Burke indicates that this type of order by identification emerges "from an attitude of individualist rejection" and moves one to "group identification." Burke's understanding of order by identification is important to Césaire's project because it provides tools through which Césaire could give voice to his rejection and break with Western philosophy, as well as his and the experience of being black in the

Journal of French and Francophone Philosophy | Revue de la philosophie française et de langue française Vol XV, No 1 (2010) | http://www.jffp.org | DOI 10.5195/jffp.2015.681 
life world. Burke's idea of order by identification becomes perhaps even more significant when taken into consideration along side Césaire's Cahier because it offers Césaire an additional framework through which he can maneuver and open up a liminal space that affords presence and autonomy to black experience in the life world.

The final lines of Césaire's Cahier demonstrate a rejection against the forces that culminate to provide a notion of Burkean "order as identification" - in these lines Césaire pushes for the dignity of all men as men and for racial equality. The strength and force of the word is present through its "metaphorical extension." ${ }_{s 8}$ Burke's notion of symbolic action can be seen in the closing lines of Césaire's Cahier:

Et nous sommes debout maintenant, mon pays et moi, les cheveux

dans le vent,

ma main petite maintenant dans son poing énorme et la force

n'est pas en nous,

mais au-dessous de nous, dans une voix qui vrille la nuit et

l'audience comme la

pénétrance d'une guêpe apocalyptique. Et la voix pronounce que

l'Europe nous a

pendant des siècles gavés de mensonges et gonflés de pestilences,

car il n'est point vrai que l'oeuvre de l'homme est finie

que nous n'avons rien à faire au monde

que nous parasitons le monde

qu'il suffit que nous nous mettions au pas du monde mais

l'oeuvre de l'homme

vient seulement de commencer

et il reste à l'homme à conquérir toute interdiction

immobilisée aux coins de sa ferveur

et aucune race ne possède le monopole de la beauté,

de l'intelligence de la force

et il est place pour tous au rendez-vous de la conquête et nous

savons maintenant

que le soleil tourne autour de notre terre éclairant la parcelle qu'à

Journal of French and Francophone Philosophy | Revue de la philosophie française et de langue française Vol XV, No 1 (2011) | http://www.jffp.org | DOI 10.5195/jffp.2015.681 
fixée notre

commandement sans limite. ${ }^{s}$

And we are standing now, my country and I, hair in the

wind, my little hand, now

in its enormous fist, and force is not in us, but above us, in a

voice which pierces

the night and the audience like the sting of an apocalyptic

hornet. And the voice

declares that for centuries Europe has stuffed us with lies

and bloated us with

pestilence,

for it is not true that the work of man is finished

that we have nothing to do in the world

that we are parasites in the world

that we have only to accept the way of the world

but the work of man has only begun

and it remains for man to conquer all prohibitions

immobilized in the corners of

his fervour

and no race has a monopoly of beauty, intelligence, strength

and there is room for all at the rendez-vous of conquest and

we know that the sun

turns around our earth, lighting only the portion that our

single will has fixed and

that every star falls from sky to earth at our limitless

command.

Césaire demonstrates Burke's notion of symbolic action here as he depicts the black man as "parasites in the world" that can only "accept the way of the world." ${ }^{\prime \prime}$ Here Césaire symbolically pushes against the Western philosophical tradition and depicts both his own and the plight of his fellow black man's being in the life world. Janis Pallister notes the "powerful assertion of racial dignity" as well as "the insistence on equality among all humans" that Césaire demonstrates in his closing lines. ${ }^{22}$ Pallister references Césaire's indication that "no race has a monopoly of beauty, intelligence,

Journal of French and Francophone Philosophy | Revue de la philosophie française et de langue française Vol XV, No 1 (2010) | http://www.jffp.org | DOI 10.5195/jffp.2015.681 
strength" "s $_{3}$ and that "there is room for all at the rendez-vous" representative of racial dignity and equality among all humans in her assessment of his closing lines. Pallister indicates that Césaire's Cahier, or what she calls a "negritude poem," possesses "function and meaning beyond its artistry" and goes "beyond the goals of most surrealist poets of the Continent." ${ }_{95}$ Pallister's assessment of Césaire's Cahier underscores the importance and utility of Burke's thought on "symbolic action" when working to uncover the full complexity and meaning present within the lines of Césaire's prose.

John McLeod interprets Césaire's Cahier to be a forceful rejection of the Western philosophical tradition and of colonialism as a system of order. McLeod indicates that Césaire "chastises blacks (and himself) for accepting too readily the white condemnation of blackness" and "urges the black population of Martinique to unite as one and realise themselves as specifically a people within the Caribbean, with their own histories and predicaments." ${ }_{96}$ For McLeod, Césaire uses Cahier as a tool to help foster a "sense of collective identity" among the Martiniquais and black beings in the life world so as to join forces with "other oppressed peoples around the world against colonial order." ${ }^{\prime \prime}$ Césaire captures this sense of solidarity and unity in the following lines of Cahier:

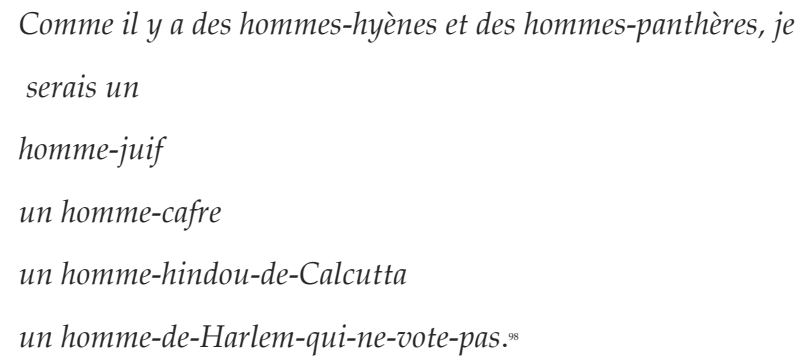

In these lines Césaire works to depict an uniform representation of suffering by symbolically representing the oppressive conditions each type of man experiences through the act of identifying, or in Burkean terms, of ordering him. McLeod indicates that "[o]ppressed peoples discover their unity in the simultaneity of their suffering rather than with recourse to a common ancestral past (African or otherwise), although that past also remains a

Journal of French and Francophone Philosophy | Revue de la philosophie française et de langue française

Vol XV, No 1 (2011) | http://www.jffp.org | DOI 10.5195/jffp.2015.681 
resource for the present." ${ }^{100}$ For McLeod, solidarity through suffering is a tool that oppressed peoples can use to "challenge" and strike against their "imprisonment by white Europeans." ${ }_{101}$ Césaire's use of symbolic language to move his fellow black man to action is represented textually in his call for unity and recognition of the simultaneity of suffering-in this case, Césaire depicts the suffering of the "hyena-men" and the "leopard-men," the "jewman," the "kaffir-man," the "hindu-man-from Calcutta," and the "manfrom-Harlem-who-doesn't-vote" in addition to his own personal suffering as a black being in the life world. ${ }^{102}$ When these lines and symbolic representations are examined symbolically, especially in light of Burke's thought on symbolic action, the multiplicity of meaning and being present in the complexity of Césaire's prose further underscores his poetic plea for autonomy for all black beings in the life world.

\section{Conclusions}

The first section of this essay concerns itself with portraying a detailed framework of Kenneth Burke's thought on symbolic action through examination of his definition of man, work on language as representative of symbolic action, and understanding of poetics and poetry. The essay surveys twelve of Burke's books and essays concerning language and symbolism so as to lay a framework for providing a coherent structuring of his thought regarding the symbolic capacity of language to embody human action. The first section of the essay begins with Burke's definition of man, paying particular attention to his definition of man as "the symbol-using animal" to highlight the significance the symbol and symbolism have for man's being in the life world. ${ }^{103}$ The first section of the essay then moves to discussion of Burke's conceptions of the symbol and its role in embodying human action through language. This section concludes with discussion of Burke's work on poetry and poetics and highlights the textual distinctions that emerge as a result of applying the semantic ideal and the poetic ideal to prose.

The second section of the essay is concerned with laying a general framework of the African philosophical project, presenting an originative and conceptual definition of Négritude, highlighting Césaire as a philosopher, politician, and poet, and with contextualizing the emergence and resounding importance of Césaire's Cahier. This section begins with an examination of the work of Placide Tempels as one of the forefathers of the African philosophical tradition. The discussion moves to a presentation of the societal attitudes of racial inclusion present in antiquity that were shattered by Enlightenment thinking. The concept of Négritude is presented and examined in terms of its historical origins and its resounding importance to the condition of being black in the life world. Césaire is linked to the Négritude movement as one of the three founding fathers and is credited with first using the word Négritude as early as 1934. ${ }^{104}$ The section

Journal of French and Francophone Philosophy | Revue de la philosophie française et de langue française Vol XV, No 1 (2010) | http://www.jffp.org | DOI 10.5195/jffp.2015.681 
concludes with discussion of Césaire as a philosopher, politician, and poet, and generally frames the conditions from which Cahier emerged as well as the poetic intentions contained within Césaire's prose.

The third section of the essay works to put Kenneth Burke's understanding of language as representative of symbolic action and his thoughts on order as identification into conversation with Césaire's Cahier. In other words, Burke's understanding of symbolic action and order as a form of identification serve as a lens through which Césaire's epic poem can be analyzed. Burke's thought on symbolic action and order as a mode of identification light up Césaire's prose and provide the reader with textual tools to assist in fully realizing and allowing the complexity of meaning and being present in the lines of the poem to emerge. Burke's work on symbolic action (and on order as identification) serves in a transformative capacity when examined in conjunction with that of Césaire's Cahier because it allows the reader to fully grasp the complexity present within being black in the world that Césaire reveals throughout the course of his epic poem.

Burke's understanding of language as representative of symbolic action offers the reader a linguistic toolkit with which to critically engage Césaire's prose so as to grasp the full complexity of meaning and being present in the lines of the poem. Burke's work allows the reader to transcend the bounds of the poem so as to work toward fully grasping the complexity of the issues that Césaire raises-which range from his own experience of being black in the world to his rejection and break from the Western philosophical tradition; from his return to Martinique to his representation of his fellow black man's being in the world. Burke's understanding of language as symbolic action allows one to transcend the literal message that Césaire's Cahier portrays, permitting the reader to permeate a deeper, contextually rich, yet hidden set of meanings representative of both Césaire's experience and perception of being black in the life world. Burke's understanding of language as representative of symbolic action allows Césaire's pleas for wholeness and unity to transcend the confines of the page so as to inspire his fellow black man to unite and take action against the oppressive colonial forces and the Western philosophical tradition, which have worked to subjugate him over the ages. Burke's work provides a clear lens through which to analyze and recontextualize the full complexity and multiplicity of Césaire's pleas for wholeness and united action present within his epic poem, Cahier d'un retour au pays natal.

${ }^{1}$ Kenneth Burke, Language as Symbolic Action: Essays on Life, Literature, and Method, $2^{\text {nd }}$ Edition (Berkeley: University of California Press, 1968), 16.

Journal of French and Francophone Philosophy | Revue de la philosophie française et de langue française

Vol XV, No 1 (2011) | http://www.jffp.org | DOI 10.5195/jffp.2015.681 
${ }^{2}$ Burke, Language as Symbolic Action, 16.

${ }^{3}$ Ibid.

${ }^{4}$ Ibid.

${ }^{5}$ Ibid., 17.

${ }^{6}$ Robert Garlitz, Kenneth Burke's Logology and Literary Criticism (Bloomington: Xlibris Corporation, 2004), 16.

${ }^{7}$ Garlitz, Kenneth Burke's Logology, 16.

8 Ibid.

${ }^{9}$ Ibid.

10 Kenneth Burke, “On Persuasion, Identification, and Dialectical Symmetry,” ed. James Zappen Philosophy \& Rhetoric 39.4 (2006): 336.

11 Kenneth Burke, Attitudes Toward History, $3^{\text {rd }}$ Edition (Berkeley: University of California Press, 1984), 179.

${ }^{12}$ Burke, Attitudes Toward History, 179.

13 Ibid.

${ }^{14}$ Kenneth Burke, A Rhetoric of Motives (Berkeley: University of California Press, 1969), 57.

${ }^{15}$ Burke, A Rhetoric of Motives, 57.

16 Ibid.

${ }^{17}$ Burke, Language as Symbolic Action, 63.

${ }^{18}$ Ibid.

${ }^{19}$ Kenneth Burke, On Symbols and Society ed. Joseph R. Gusfield (Chicago: University of Chicago Press, 1989), 78.

${ }^{20}$ Burke, On Symbols and Society, 77.

21 Ibid.

22 Ibid.

${ }^{23}$ Ibid.

24 Ibid., 79.

25 Kenneth Burke, Permanence and Change: An Anatomy of Purpose, $3^{\text {rd }}$ Edition (Berkeley: University of California Press, 1984), 66.

${ }^{26}$ Burke, Permanence and Change, 66.

27 Ibid.

28 Kenneth Burke, The Philosophy of Literary Form: Studies in Symbolic Action, $3^{\text {rd }}$ Edition (Berkeley: University of California Press, 1973), 147.

${ }^{29}$ Burke, The Philosophy of Literary Form, 147.

Journal of French and Francophone Philosophy | Revue de la philosophie française et de langue française Vol XV, No 1 (2010) | http://www.jffp.org | DOI 10.5195/jffp.2015.681 
30 Ibid., 147-148.

31 Ibid.

32 J. Obi Oguejiofor, "Problems and Prospects of a History of African Philosophy," American Catholic Philosophical Quarterly 77.4 (2003): 484.

${ }^{33}$ Oguejiofor, "Problems and Prospects," 484

${ }^{34}$ Ibid.

35 Ibid., 485.

36 Fidelis U. Okafur, “Issues in African Philosophy Re-examined," International Philosophical Quarterly 33.1 No. 129 (1993): 95.

37 J. Obi Oguejiofor, “Negritude as Hermeneutics: A Reinterpretation of Léopold Sédar Senghor's Philosophy,” American Catholic Philosophical Quarterly 83.1 (2009): 86.

${ }^{38}$ Oguejiofor, “Negritude as Hermeneutics,” 86.

${ }^{39}$ Christian Filostrat, Negritude Agonistes: Assimilation against Nationalism in the French-speaking Caribbean and Guyane (Cherry Hill: Africana Homestead Legacy Publishers, 2008) 123-128.

${ }^{40}$ Chukwudum B. Okolo, “Negritude: A Philosophy of Social Action,” International Philosophical Quarterly 24 (1984): 427.

${ }^{41}$ Okolo, “Negritude," 429.

${ }^{42}$ Burke, Language as Symbolic Action, 16.

${ }^{43}$ P. Chike Onwachi, African Identity and Black Liberation (Buffalo: Black Academy Press, 1972), 123.

${ }^{44}$ Onwachi, African Identity, 123.

45 Aimé Césaire, Discourse on Colonialism, trans. Joan Pinkham (New York: Monthly Review Press, 1972), 92.

${ }^{46}$ Césaire, Discourse on Colonialism, 92.

47 Ibid.

48 Janis L. Pallister, Aimé Césaire (New York: Twayne Publishers, 1991), xii.

${ }^{49}$ Michael Rothberg, Multidirectional Memory: Cultural Memory in the Present eds. Mieke Bal and Hent de Vries (Stanford: Stanford University Press, 2009), 72.

${ }^{50}$ Rothberg, Multidirectional Memory, 72.

${ }^{51}$ Gregson Davis, Aimé Césaire (Cambridge: Cambridge University Press, 1997), 13.

${ }^{52}$ Davis, Aimé Césaire, 13.

53 Ibid.

${ }^{54}$ Sylvia Wynter, "The Pope Must Have Been Drunk, The King of Castile a Mad Man: Culture as Actuality, and the Caribbean Rethinking Modernity," in The Reordering of Culture: Latin America, the Caribbean, and Canada in the Hood, eds. Alvina Ruprecht and Cecilia Taiana (Ottawa: Carleton University Press, 1995), 32.

Journal of French and Francophone Philosophy | Revue de la philosophie française et de langue française Vol XV, No 1 (2011) | http://www.jffp.org | DOI 10.5195/jffp.2015.681 
${ }^{55}$ Wynter, “The Pope Must Have Been Drunk,” 32.

56 Ibid.

${ }^{57}$ Amanda Stansell, "Surrealist Racial Politics at the Borders of 'Reason': Whiteness, Primitivism, and Négritude," in Surrealism, Politics, and Culture eds. Raymond Spiteri and Donald LaCoss (Burlington: Ashgate Publishing Company, 2003), 125.

${ }^{58}$ Bernard L. Brock, Kenneth Burke, Parke G. Sturgess, and Herbert W. Simons, "Dramatism as Ontology or Epistemology: A Symposium,” Communication Quarterly 33.1 (1985): 25.

${ }^{59}$ Brock et al., “Dramatism as Ontology or Epistemology," 25.

${ }^{60}$ Burke, Language as Symbolic Action, 16.

${ }^{61}$ Kenneth Burke, “Postscripts on the Negative," Quarterly Journal of Speech 39.2 (1953): 209.

${ }^{62}$ Burke, "Postscripts on the Negative," 209.

63 Ibid.

${ }^{64}$ Kenneth Burke, “Dramatism and Logology,” Communication Quarterly 33.2 (1985): 93.

${ }^{65}$ Burke, “Dramatism and Logology," 93.

66 Ibid.

${ }^{67}$ Ibid.

${ }^{68}$ Pallister, Aimé Césaire, xii.

${ }^{69}$ Michael Richardson and Krzysztof Fijalkowski, trans., Refusal of the Shadow: Surrealism and the Caribbean (New York: Verso/New Left Books, 1996), 6.

${ }^{70}$ Richardson and Fijalkowski, Refusal of the Shadow, 6.

71 Ibid.

72 Ibid., 6-7.

${ }^{73}$ Ibid., 7.

${ }^{74}$ Ibid

${ }^{75}$ Aimé Césaire, "Poetry and Knowledge," in Refusal of the Shadow: Surrealism and the Caribbean, trans. Michael Richardson and Krzysztof Fijalkowski (New York: Verso/New Left Books, 1996): 140.

${ }^{76}$ Césaire, “Poetry and Knowledge," 140.

${ }^{77}$ Césaire, Discourse on Colonialism, 68.

78 Ibid.

${ }^{79}$ Kenneth Burke, “A Dramatistic View of the Origins of Language,” Quarterly Journal of Speech 39.2 (1953): 88.

${ }^{80}$ Burke, “A Dramatistic View," 88.

81 Ibid.

82 Ibid.

Journal of French and Francophone Philosophy | Revue de la philosophie française et de langue française Vol XV, No 1 (2010) | http://www.jffp.org | DOI 10.5195/jffp.2015.681 
${ }^{83}$ Burke, The Rhetoric of Religion: Studies in Logology (Berkeley: University of California Press, 1961), 4-5.

${ }^{84}$ Burke, The Rhetoric of Religion, 4.

${ }^{85}$ Ibid., 4-5.

${ }^{86}$ Burke, “War and Cultural Life," American Journal of Sociology 48.3 (1942): 406.

${ }^{87}$ Burke, "War and Cultural Life," 406.

${ }^{88}$ Burke, “A Dramatistic View," 88.

${ }^{89}$ Aimé Césaire, Cahier d'un Retour au Pays Natal (Paris: Éditions Présence Africaine, 1983), 57-58.

${ }^{90}$ Aimé Césaire, Cahier d'un Retour au Pays Natal, trans. Emile Snyder (Paris: Éditions Présence Africaine, 1971), 138-140.

${ }^{91}$ Césaire, Cahier, trans. Emile Snyder, 138.

${ }^{92}$ Pallister, Aimé Césaire, 23.

${ }^{93}$ Ibid.

${ }^{94}$ Césaire, Cahier, trans. Emile Snyder, 140.

${ }^{95}$ Pallister, Aimé Césaire, 23.

${ }^{96}$ John McLeod, Beginning Postcolonialism (New York: Palgrave, 2000), 80.

${ }^{97}$ McLeod, Beginning Postcolonialism, 80.

${ }^{98}$ Césaire, Cahier, 20.

${ }^{99}$ Césaire, Cahier, trans. Emile Snyder, 56.

${ }^{100}$ McLeod, Beginning Postcolonialism, 81.

101 Ibid.

${ }^{102}$ Césaire, Cahier, trans. Emile Snyder, 56.

${ }^{103}$ Burke, Language as Symbolic Action, 16.

104 Pallister, Aimé Césaire, xi. Pallister indicates that Césaire "evidently" first introduced the word Négritude in 1934 in an article published in the journal L'Étudiant Noir that he co-founded with Léopold Sédar Senghor and Léon-Gontran Damas. Pallister's account of Césaire's first use of the word Négritude is in contrast with the account offered by Christian Filostrat in Negritude Agonistes: Assimilation and Nationalism in the French-speaking Caribbean and Guyane. In this text Filostrat reproduces a copy of the May-June 1935 issue (issue 1.3) of L'Étudiant Noir wherein Césaire first uses the word Négritude in print (see pages 123-128 of Negritude Agonistes for a reproduction of issue 1.3 of L'Étudiant Noir). Filostrat's account of Césaire was first published in 2008 whereas Pallister's went to press in 1991-suggesting that the May-June 1935 issue of L'Étudiant Noir may not have been available to Pallister when she composed her account of Césaire.

Journal of French and Francophone Philosophy | Revue de la philosophie française et de langue française Vol XV, No 1 (2011) | http://www.jffp.org | DOI 10.5195/jffp.2015.681 